\title{
Implementation of Language Politness principles in Indonesian Language Learning Discussion Activities
}

\author{
Della Rency Melia Indah \\ Bengkulu State Institute of Islamic Religion \\ dellarency56@gmail.com \\ Kasmantoni \\ Kasmantoni1975@gmail.com \\ Bengkulu State Islamic Institute \\ Bustomi \\ Bengkulu State Islamic Institute \\ Bustomihasan@iainbengkulu.ic.id
}

\begin{abstract}
This research is motivated by Indonesian Language Learning which requires students to master the six politeness principles. Namely the maxsim of wisdom, the maxsim of generosit, the maxsim of praise, the maxsim of humility, the maxsim of agreement, and the maxsim of sympathy. In class VIII A SMP Negeri 1 Kikim Tengah in discussion activities. The writing is the study exsamines how the implementation of politeness in Indonesian Language learning in class VIII teacher and students of SMP Negeri 1 Kikim Tengah, Lahat Regency during a discussion and what are the factors for violating the maxsims in the discussion. The type of this research is descriptive qualitative research. The subjects of this research are students of class VIII A SMP Negeri 1 Kikim Tengah, Lahat Regency, Meanwhile, the informants of this research are Indonesia Language Teacher at SMP Negeri 1 Kikim Tengah, Lahat Regency. The results of this study concluded that the implementation of politeness principles in student discussion activities, namely opening, explaining, question and answer, closing. The discussion process for students must be more thorough in mastering the principles of politeness in Indonesian language learning discussion activities, and the lecture method
\end{abstract}

Keywords: Language Politeness, Discussion, Language Learning.

\section{A. Introduction}

In close-knit communities will be the language is a tool of interaction. With the language, it will make it easier for us to communicate, therefore people can interact with each other so that interactions between people can take place within the community and in the world of education such as schools and classes as well as in the surrounding environment, the role of the teacher as an educator is a role related to the task, the task of providing assistance and encouragement as well as tasks related to disciplining children, so that children become obedient to the rules . 
Politeness is also a matter of paying attention to the degree of dignity of others in using language, when using spoken language, or using writing. This rule is carried out in order to keep a relationship between the speaker and the speech partner from making mistakes in communicating and interacting between the two. Comunication have a rule that rules are contained in the principles of politeness had 6 (six) politeness principle, namely: the maxim of wisdom, maxims generous, maxims praise, maxims heart, maxims agreement, and maxims kesimpatipenutur and opponents can establish communication well on both of them.

In communicating, there are several maxims of rules, maxims of wisdom where in this maxim that politeness is often referred to as a civilized act, but the more important meaning obtained from courtesy is the missing link between the problem of how to link power with meaning, the maxim of generosity means make your own profit as much as possible. Bilateral illocutionary aspects. is positive and commissive, while the maxim of praise can be said like this, praise others as much as possible "this maxim of praise is usually also called the maxim of seduction or commonly referred to as insincere praise, the maxim of humility is speech to be humble by reducing praise to oneself The maxim of agreement emphasizes that the speech participants can foster compatibility or agreement in speaking activities, and the last maxim of sympathy is speech that maximizes the attitude of sympathy between one party and another.

Discussion should be able to apply how we use the language well, discussion in the classroom not only how we talk alone but should be able to adjust the position of language desperate to reveal something so contrary to cooperate or discuss in class. Speak in a discussion at class or in society has a maxim of politeness in the language. The quality and quantity in the language must be very important to remember in the discussion, because the quality of language would be a reflection of how we behave well in using the language quality and quantity of the

\section{B. Research Method}

This study uses a descriptive-qualitative design. Qualitative descriptive design is used to obtain a clear, objective, systematic, and accurate picture of the actual facts. This study aims to describe the implementation of language politeness in classroom learning, students' language politeness to be achieved by the teacher, and students' speaking activities in the classroom. class. The source of this research data was obtained from one of the junior high schools in Lahat City, where the focus of the research was carried out during classroom learning on Indonesian language subjects, and the object of research focused on the language spoken by students during the teaching and learning process. Then the data is collected based on the principle of politeness in language. The 
resource persons come from teachers and junior high school students who carry out the teaching and learning process in the classroom in Indonesian language courses.

This research uses descriptive qualitative research. Qualitative descriptive research, namely research that aims to produce descriptive data in the form of written or spoken words from people and observable behavior. The data obtained cannot be expressed in the form of numbers or statistical figures.

The data subjects and informants used in this study were recordings of teaching and learning interactions that occurred in class VIII A of SMP Negeri 1 Kikim Tengah, Lahat Regency. which is taking place. Video recordings of conversations used as data for this research include matters relating to the application of the principles of politeness in language.

\section{Results and Discussion}

\section{Results}

The realization of the use of Indonesian that violates the principle of language politeness in the discussion activities of class VIII A students of SMP Negeri 1 Kikim Tengah, Lahat Regency occurs because it is influenced by internal factors, such as (1) different levels of students' speaking abilities who are still carried away by the local language, (2) courage students in expressing opinions, and (3) the level of students' understanding of the topic of discussion. In addition to internal factors, there are external factors that also affect the violation of the principle of cooperation in the discussions of class VIII A students of SMP Negeri 1 Kikim Tengah, Lahat Regency. The external factor is the Indonesian language lesson schedule which is at erratic hours so that students' focus in discussing decreases. The class atmosphere also became less conducive because some students did not pay attention and some even joked with their friends.

The principle of politeness in language does not completely have a negative impact. The existence of the principle of politeness in language in discussion activities is able to make students more familiar, for example with the teacher's humor or there are student speeches that are not relevant to the topic of discussion. This can make other students help in providing answers or relevant topics. Based on research which states that studies that apply the principle of politeness in language are able to show the character education potential of the object of study during discussions.

\section{a. Maxim's Form in Discussion}

1. Maxim of Wisdom

The maxim of wisdom or it can be called the maxim of wisdom that courtesy is often called civilized action. Leech said that this wisdom maxim has its presence in the speech partner. maxim it refers to the self-image of each person to be appreciated 
giving praise and is a form of recognition given to the opponents said, however on this maxim make another person's loss as small as possible or add the benefit of another, it can be seen in the following dialog.

\section{Example 1:}

1 : Student 1 : do you understand?

2 : Student 2 : Sorry, I already understood from Kartika's explanation, but can it be repeated so that I can understand better.

\section{Example 2:}

Questioner : Can the presenter repeat the answer!

Teacher : I want the presenter to repeat the answer from sister Nabila.

Presenter : Okay. I will repeat the answer to sister nabila's question.

The first example above is an example of data that violates the maxim of wisdom or wisdom. This can be seen in the answer to the presenter. In this example, students ask a lot of questions because they are selfish, but this maxim can be applied during the discussion that one must be wise in doing and carrying out a discussion activity in language. Another evidence that strengthens this reason is the existence of what words can be repeated so that I understand better. The sentence is a word used to provide an understanding that students can respond wisely to the questions in the discussion activities. The second example above is also a maxim of wisdom in the sentence can the presenter repeat the answer!. And a statement from a teacher I want the presenter to repeat the answer from sister nabila. The data also shows that students and teachers use the maxim of wisdom or wisdom, with students giving statements to repeat the answers by the presenter. Responding to this, the presenter will answer wisely so that the answer is easier to understand and appropriate.

\section{Maxim of Generosit}

Maxim of generosit careful that students have to make a profit themselves as possible. Leech said that the rules are expected to be respectful of others. Respect for others will occur when people can maximize their own losses and maximize their own gains. In the discussion activities, students turned out to have fulfilled the maxim of generosity as stated in the following speech.

\section{Example 1:}

Moderator : is granted to Adelia to read further material.

Student : ok, assalammualaikum, I am Adelia Patrisca as presenter 1 will explain my material.

Teacher : Moderator's voice, thank you very much! 
Moderator : Yes ma'am!

\section{Example 2:}

Moderator : presenters can answer easier questions first.

Presenter : OK, thanks to the moderator.

The example above is a conversation between a teacher and a student. At that time, the teacher gave advice to the students who acted as moderator. After the presenter reads the material, the moderator says to the readers of the next material, Adelia is invited to read the next material. speech of students that are welcome to read the material Kartika further categorized into the application of the maxim of generosity, the award to others because these utterances meaningful honor or give awards to other people. Another evidence that strengthens this reason is the presence of the word welcome which is a word used in giving appreciation or respect to others. because students are still respected and given awards by moderators who are also students to guide the discussion. The example above can also be proven by greeting greetings to start presenting the material to the discus participants. The data also shows that students seem to appreciate and respect teachers and group participants in activities. While the second example above can also be said to be the maxim of generosity, it can be seen from the evidence in the statement that the moderator provides an opportunity for the presenter to answer easy questions. This statement is answered by the presenter. $O K$, thanks to the moderators. This data shows that the presenter responds to the moderator's words, it can be seen that the presenter responds swiftly, it can be seen that applying the maxim of generosity in discussion activities is very important

3. Maxim of Praise

The maxim of praise can be said that criticize others as little as possible, praise as many people as possible. Leech said that this maxim is also a flattering maxim or commonly called an insincere compliment. but the negative do not say unpleasant things about other people especially about the speaker. In these discussion activities, the maxim of praise can be interpreted in two ways, praise is good or offends in conveying a sentence and deed. As the following example.

\section{Example 1:}

Teacher : Your answer is very good.

Student : thank you sir .

Example 2:

Presenter : with my explanation do you understand? 
Student : yes! Presenter's answer is very good !. But unfortunately I do not quite understand.

\section{Example 3 :}

Student : Assalamualaikum sir, sorry I'm late.

Teacher : wow! Very good!! hours by now was coming.

The example above is a maxim of praise that can be called a good compliment. This can be proven by your very good answer. The sentence looks like the teacher praises the students' answers. In discussion activities, there is a presenter's satisfaction in answering questions and praise from a teacher for a very good and satisfying answer. The first example statement is a good maxim of praise. Will remain in the second and third examples, is a negative maxim of praise. This is evidenced by the statement that the student is not satisfied with the presenter's answer but uses a soft sentence but satirizes the sentence yes! Presenter's answer is very good!. But unfortunately I do not quite understand. And in the third example, it can be proven in the conversation of a teacher who responds to his students late, wow! Very good!! hours by now was coming. From the statement of the second and third example sentences that the students and teachers use the negative maxim of praise, the sentence can be seen that it is included in the maxim of praise that is not sincere or not good.

4. Maxim of Humility

Maxsim humility is to make students to be humble to reduce i compliments to yourself, Leech said that the maxim of modesty or humility maxim of participants said to be humble with how to parse a compliment to ourselves. In the activity of a discussion, it can be said that many people speak a language that praises and favors themselves. However, during the activity, the principle of politeness in language must be able to apply the maxim of humility in the discussion. This can be seen in the following dialogue.

\section{Example 1:}

Student 1: Sorry in advance, can the presenter be more able to explain the answer to the question than me?

Presenter : sorry if the answer is not satisfied, we feel a little difficult, okay to other participants can help answer the question sister puja!

Teacher : is there anyone who is willing to help group 1 ?

\section{Example 2 :}

Presenter : sorry sir, we ask for help to explain a little about the material we convey, so that discussion participants can understand better. 
Teacher: I will explain a few questions and answers from this discussion.

Example 3 :

Presenter : can anyone add to or help our answer?

Student : OK, I 'll try to add and explain the answer a little! Looks like group one is having a really hard time.

Moderator : thank you for helping answer this question.

The example above is an application of the maxim of modesty or humility. This can be proven by an apology from the presenter for students who ask. With the attitude given that students have a humble attitude to ask for help in order to answer the question. The second example above is also a humble attitude that can be proven by asking a teacher for help so that he can explain a little about the questions of other students, because in discussion activities, humility towards friends and a teacher really needs to be applied in a discussion activity. There is also the third example above, it can be seen in students who want to help the presenter in answering questions, well I will try to add and explain a little of the answer! It looks like group one is having a lot of trouble. This shows the humility of students to help their friends in answering difficult questions. This maxim needs to be applied when discussing activities.

\section{Maxim of Agreement}

The maxim of agreement is the maxim of speech that fosters mutual and compatibility or agreement in speaking or discussing activities. Chaer states that the maxim of agreement requires that every speaker and interlocutor. By maximizing agreement between a discussion among students and minimizing disagreement in opinion or discussion. This can be seen in the following dialogue.

\section{Example 1:}

Student: I agree with the presenter's answer about how to behave in a game.

Teacher : yes, it is true that what the presenter said is the right answer

\section{Example 2 :}

Group 3: I strongly agree with the answers from group 1, but here I want to add little.

Group 4: yes I agree with what group 3 said.

Example 3 :

Moderator : Can the minutes conclude our discussion today.

Minutes, all right, thanks to the moderators.

Teacher : with the conclusion that has been explained in the minutes, you agree with the conclusion. 
Example one above is a maxim of agreement or can be said to be consensus, it can be proven in the sentences of the teacher and students I agree with the answer of the presenter and the teacher stating yes, it is true that what the presenter said is the right answer. Maxim in discussion activities like this really needs to be applied. The example above can be said to be a maxim of agreement because there is agreement in the opinion of a discussion and the answer given by the presenter. It is said that students and teachers strongly agree about the answers given by the presenter.

Examples of the second and third on top is also a maxim of agreements or arguably agreement, evidenced by conversation group 3, I strongly agree answers from Group 1, but here I want a bit downloading ambahkan and the sentence, yes I agree with what the group 3 deliver. What was said by group 4 that there was agreement between groups in adding answers from the presenter. Likewise in the third example where there is agreement on the conclusions of the note taker and the teacher. This maxim is very necessary in a discussion activity so that it can run well, because in a discussion there will be consensus on questions and answers that must be straightened out and resolved.

6. Maxim of Sympathy

The sympathy maxim requires students to maximize their sympathy towards other students, Chaer said that the sympathy maxim requires all speaker participants to give sympathy. When the interlocutor gets luck or happiness, the speaker must give congratulations. Meanwhile, if the interlocutor gets into trouble or misfortune, the speaker can convey his sorrow as a sign of sympathy during discussion activities. The principle of politeness in language with an attitude of sympathy for others can uphold a sense of courtesy towards others. As an example of the following dialogue.

\section{Example 1:}

Teacher : congrats yes, with the added answer, can make other friends understand.

discussion student : I really sympathize with sister Niken's response.

Moderator : OK, thank you for running the discussion well and regularly and for those of you who have trusted me to be the moderator of today's discussion.

\section{Example 2 :}

Moderator : Thank you, I will close this discussion by saying hamdalah.

Teacher : congratulations on a good job in guiding the discussion today.

Example 3 : 
Teacher: I really sympathize with the answers and responses by the discussion group today.

Group 1: Alhamdulillah, thank you for your sympathy, sir .

The first example above shows that there is an attitude of sympathy for someone by giving good answers to discussion activities. With the sentence congratulations yes and the sentences of gratitude from the moderator, it can be concluded that the trust stated that teachers and students give sympathy by saying congratulations and thank you. The application of language politeness to see and make the maxim of sympathy provides Indonesian language learning to students how to sympathize with others.

The second and third examples above are also sympathy maxims, it can be seen from the conversation between the moderator, teacher, and group. The maxim of sympathy can also be applied in learning activities, especially discussion activities, so that teachers and students can apply the principle of politeness in language in the maxim of sympathy.

It can be concluded that the explanations and examples above are teaching and learning activities and discussion activities in the classroom, especially Indonesian language learning really requires the principles of language politeness and maxims that must be applied by teachers and students, in order to make it easier to make discussion activities more interesting. effective and good.

\section{Discussion}

Several experts who discuss language politeness include Lakoff (1972), Fraser (1978), Brown and Levinson (1978), and Leech (1983). In general, according to experts, there are three rules that must be followed to the speech sounds mannered by opponents said, namely (1) the formalities (formality), (2) indecision (hesitancy), and (3) the similarity or kesekawanan (equality or camaraderie) (Chaer, 2010). In the first rule, namely do not force or do not be arrogant to the interlocutor; the second rule, which is to make it in such a way that the interlocutor or the interlocutor can determine the choice (option ); and the third rule, which is to act as if you and your interlocutor are the same or in other words 'make your interlocutor happy'. Based on the theory that has been mentioned, the researcher focuses on Leech .'s theory of politeness.

Based on the data obtained in the field regarding the Implementation of Politeness in Indonesian Language Learning in Class VIII A Teachers and Students of 
SMP Negeri 1 Kikim Tengah, Lahat Regency During Discussion, the authors describe the implementation and errors during the discussion.

The application of Indonesian language learning is a process carried out by teachers and students in carrying out discussions in class, in the discussion section in class VIII A of SMP Negeri 1 Kikim Tengah as well as learning activities in general, namely, material distribution, preparation, discussion and evaluation. By using the right methods, media, approaches, strategies, and techniques so that discussions can run smoothly and well.

Implementation of Indonesian language learning in class VIII A, on the distribution of materials and preparations that will be conveyed during the discussion. the teacher will explain a little learning material according to the method used by the teacher. When explaining the material and distributing the material to be discussed, the teacher must also pay attention to and direct the attitude when using the maxims that the teacher and students learn in discussing, such as procedures for starting, explaining, asking and answering.

After explaining the distribution of materials and preparation, teachers will encourage students un t uk implement and begin memperaktekkan discussion in group 1 which is set up a table for the minutes, and the moderator as a regulator of the conversation progresses, the table for the material menyaji 1,2,3 and discussants. The teacher will monitor how students discuss using Indonesian properly as well as using the existing maxims. The teacher will see the activity and language used during the question and answer session with a session that has been determined by the moderator.

\section{A. Opening}

Before starting the discussion, it would be better if the moderator opened a discussion properly explaining what material will be discussed, introducing himself and who will present the material presented using polite language "assalammualaikum, good morning introduce my name Redy Eka Setiawan as a moderator and beside me Desta Alfina as a note taker, here I will introduce our presenters today, namely Adelia Patrisca as presenter 1, Hanafia as presenter 2, and Kartika as presenter 3. Alright, presenters are welcome to explain the material ".

B. Explain

After the moderator opens the discussion, the presenter will explain the material that has been previously shared by the teacher, the presenter must 
also be able to use the language and maxim rules of politeness in language when explaining the material presented in the discussion activity.

"Well, assalammualaikum, I am Adelia Patrisca as presenter 1 will explain my material and will continue to presenter 2 and $3 "$.

C. Question and answer

In this session the moderator will guide which group will ask the presenter, and the question is written by the note taker. After the question session is over, the presenter will discuss the appropriate answers in order to understand and accept good and correct answers.

D. Closing

Where the minutes will conclude the material and questions as well as answers that have been carried out in the discussion activities, after which they will be closed by the moderator.

"Well, that's the material presented by the presenter and the conclusions conveyed by the note taker. I, once the moderator of today's discussion, resigned thanks to the group participants who participated in this discussion, more or less I apologize. I end assalammualaikum warohmatullah hiwabarokatu"

The teacher also plays a role in directing if there is a misunderstanding or if the answer is not right to be able to launch a good discussion. Evaluation here, the teacher will assess the language skills and activeness of students during discussions, evaluate understanding and the ways and maxims used in the discussion. Reviewing and explaining also assessing the material that has been conveyed by the presenter as well as the questions and answers by the discussion participants.

This study also focuses on what methods are used by teachers to assist the discussion in learning Indonesian in class VIII A of SMP Negeri 1 Kikim Tengah, Lahat Regency. The method used is the discussion method, the repetition method. And the lecture method In order to be able to hear and digest the explanations carried out how a good discussion activity and what maxims are appropriate and may be used in discussions.

The method used by a teacher can train the activeness of students and can practice language skills in discussion. The application of this method in learning Indonesian in Class VIII A of SMP Negeri 1 Kikim Tengah. By discussing the teacher can see the development of language skills in fluency during discussions. 
Based on these explanations, the author analyzes and concludes the language politeness and maxims used by teachers and students in class VIII A of SMP Negeri 1 Kikim Tengah, Lahat Regency. With supporting factors in discussion activities in Indonesian language learning classes.

From the explanation above regarding the implementation of the principle of politeness in language, one of the Indonesian language teachers at SMP Negeri 1 Kikim Tengah, Lahat Regency, Mr. Meirzah, S, Pd stated that in a discussion activity there must be arrangements so that the discussion runs well, thus the principle of politeness in language is very important in order to making a discussion activity run according to the predetermined principle rules, that's why it is important to have a moderator, note taker, and presenters and discussion participants.

Applying the principle of politeness as a teacher must master what are the appropriate maxims when teaching in order to be able to apply them to students how to convey opinions, suggestions or explain a material. With that, the application of the principle of politeness can run with the activities of the teaching and learning process and discussion. However, in the classroom in carrying out a teaching and learning process or discussion there are obstacles, namely the first language factor, where often students who still use the local language and do not master the language in the learning process activities, the second factor inhibits discussion about the material, students often have difficulty in mastering and understanding the material. Finally, in discussing the inhibiting factors, they still do not understand the word questions, such as who, where, how and when .

\section{E. Conclusion}

Implementation of learning in discussion activities, namely, preparation, implementation, evaluation. Implementation of discussion activities in the politeness of Indonesian language learning, namely how the ability of students to apply the principles of language properly and regularly when the teacher can help the learning process run well, in a discussion activity a student and teacher must be able to work together in applying the principles politeness in language in order to make learning Indonesian more fluent and accustomed to using good Indonesian without involving local languages during the teaching and learning process in the classroom, especially when learning Indonesian. 
The maxim violation factor often occurs during the learning and discussion process, but these factors can have both good and bad impacts on learning. However, with the implementation and application carried out by the teacher and applied by students, it can make the implementation of Indonesian language learning good when the principle of language politeness runs by the teaching and learning process carried out by the teacher and students during the discussion .

\section{Reference}

Ani, R. et al. (2018). Politeness Principles Based on the LEECH Maxim in Collecting Scripts of The Toilet Gang Drama by LEAK Sociawan and Its Relevance as Teaching Material for Drama Texts in High Schools. Journal of Language, Literature, and Teaching. 6(2),3.

Annisa, N.A. (2018). Principles of Language Politeness Between Tour Guides And Japanese tourists at Prambanan Temple (Pragmatic Analysis Study). Journal of Education. 12(1),33.

Asih. (2016). Indonesian Language Learning Strategies. Bandung : CV Pustaka Loyal.

Chaer, A. (2010). Language Politeness . Jakarta: Rineka Cipta.

Chaer, A., and Agustina, L. (2014). Sociolinguistics . Jakarta: Rineka Cipta.

Deka, A. et al. (2020). politeness of language as a determinant factor success in language learning. Journal of Literature and Teaching. 1(2), 4.

Dawn, P. (2018). Politeness in Children's Language to Parents in the Environment Family. Journal of Language Politeness, Learning. 1(1), 23.

Jumanto. 2017. Prakmatics: The World of Linguistics Is Not As Wide As Moringa Leaves Edition 2.Yogyakarta: Morfalingua.

Leech, G. (2011). Principles of Pragmatics (Translated by MDD Oka and Setyadi Setyapranata). Jakarta: University of Indonesia Publisher.

Lili, M., et al. (2020). Student Language Politeness With Indonesian Teacher Via WhatsApp Social Media at SMP Negeri 2 Bukittinggi. Indonesian Language and Literature Journal. 9(4), 23.

Moleong, L.J. (2017). Qualitative Research Methodology (Revised Edition) . Bandung: PT Youth Rosdakarya.

Moleong. (2010). Qualitative Research Methodology. Bandung: Rosada Teens Work.

Nuri Gustriani et al. Indonesian Language Teacher Politeness in Process Teaching and Learning at SMA Negeri 2 Rintau Buo. Journal of Indonesian Language and Literature Education. 1(1), 2.

Rahardi, R. K. (2005). Pragmatics: Indonesian Imperative Politeness . Jakarta: Erlangga.

Rusminto, N.E. (2015). Discourse Analysis of Theoretical and Practical Studies .Yogyakarta: Graha Ilmu.

Sardiana. (2006). Politeness in Indonesian for Class VII Students of SMP Negeri 1 Lilirilau, Soppeng Regency. Thesis on FBS Makassar State University: unpublished.

Sugiyono. (2017). Qualitative, Quantitative, and R\&D Research Methods. Bandung: Alphabeta CV. 
Syaifuddin. (2006). Learning Design and Its Implementation, (Ciputat: PT. Quantum Teaching)

Pranowo. (2017). Language Learning Theory (For Language Teachers And Students Language department). Yogyakarta: Learning Library.

Purwati, N.M.A. Rasna, I. W., and Wisudariani, N.M.R. (2017). Principles of Politeness in Talk Show Rumpi (No Secret) on Trans TV". Ejournal Ganesha University of Education Department of Indonesian Language and Literature Education 6(1), 1-10.

Tarigan, H.T . (2009). Language Learning Methodology. Bandung: Space.

Wenny, W, et al. (2018). Language Politeness in the Learning Process at Primary school. Journal of Language Politeness, Learning. 2(1), 8.

Wulandari, Agustina, and Ngusman. (2015). Mario Teguh Expressive Speech Act in the Golden Ways Show. Journal of Language, Literature, and Learning , 2(1), 99-113.

Yule, G. (2014). Pragmatics . Yogyakarta: Student Library.

Yulistio, D. (2013). Indonesian Language For Higher Education . Bangalore: UNIB Press. 